\title{
Nanomole per Day
}

National Cancer Institute

\section{Source}

National Cancer Institute. Nanomole per Day. NCI Thesaurus. Code C85751.

Nanomoles per day. 